\title{
Tulevaisuuden kuvittelun tarpeesta
}

Nykyhetken maailmantila herättää huolta ja levottomuutta. Twitter-myrskyjen kiihdyttämät uutiset poliittisista kriiseistä, mielenosoituksista, vallankaappauksista ja luonnonkatastrofeista pitävät meitä intensiivisesti pyörteissään. Muistiin tarttuvat ennen kaikkea negatiiviset ja järkyttävät tapahtumat. Olemme tietoisia yhtäaikaisista taloudellisista, poliittisista ja ekologisista kriiseistä, joille ei ole nopeita ratkaisuja. Tulevaisuuteen ei ole pitkäkantoisten kriisien keskellä helppo suhtautua toiveikkaasti. Tulevaisuuden ajatteluun - tai sen kuvitteluun sellaiseksi, jossa nykyhetken ongelmiin olisi löydetty ratkaisu tarvitaan avuksi mielikuvitusta, spekulointia ja kykyä haastaa ajattelun rajoja. Se vaatii - Donna Harawayn $(2016,10)$ metaforaa lainataksemme - narukuvioleikkejä, joissa uudet kuviot syntyvät jakamalla ja vastaanottamalla muodostelmia, pudottamalla ja nostelemalla lankoja.

Kun maailmantilan katastrofaalisuus vyöryy ylitsemme, kirjallisuus - tuo hidas media - ei ole kadottanut kykyään raottaa utooppisia ulottuvuuksia. Tulevaisuuden mahdollisuuksien kuvittelussa kaunokirjallisuus on omaa luokkaansa, sillä emme odota tarinoiden tarjoavan konkreettisia ratkaisuja. Kirjallisuus herättelee pikemmin kuin ohjaa meitä miettimään vaihtoehtoja ja niiden myötä avautuvia tulevaisuuksia. Kirjallisuuden tulevaisuuskuvien vahvuus on myös siinä, että ne inhimillistävät vaikeasti hahmotettavia muutoksia ja kannustavat kuvittelemaan, miten maailmassa voisi selvitä esimerkiksi katastrofin jälkeen (Ameel et al. 2020, 98).

Tulevaisuuden visiointi, oli se sitten utopian tai dystopian vaatteissa, yhdistetään useimmiten spekulatiiviseen fiktioon, vaikka utooppiset välähdykset kietoutuvat nykyromaaniin mitä moninaisimmilla tavoilla niin sisällön, muodon kuin funktion tasoilla. Nykykirjallisuutta sävyttää myös historiankulun ja erilaisten väkivallan historioiden ruotiminen, mikä ei ole vain menneisyyttä kohti haparointia vaan muutosvoimaista, uusia perspektiivejä avaavaa toimintaa. Tulevaisuus ajallisena ulottuvuutena on useimmiten märittelemätön toiveikkuuden horisontti, ei menneisyydestä nykyisyyden kautta tulevaan johtava selkeä reitti.

Kirjallisuudentutkimuksella ja kirjallisuudesta käydyllä keskustelulla on merkittävä rooli utooppisten nyanssien ja kerronnallisen ajattelun avaamisessa. Utooppisuuden tarve ja ilmaisut ovat aina sidoksissa yhteiskunnalliseen tilanteeseen, aikakauteen ja historiaan. Kirjallisuudentutkimuksen näkökulmissa yhdistyvät teoreettisen spekuloinnin ja käsitteellisten keskustelujen lisäksi historiantuntemus ja aikakausiin sidottujen kertomusten ymmärrys. Tarvitsemme sekä käsitteellisiä että historiankulkua hahmottavia keskusteluja ymmärtääksemme syvemmin paitsi nykykirjallisuuden utooppisuuden kirjoa myös epävarmuuden tunteita ruokkivaa maailmantilaa. 
Vuoden ensimmäisessä numerossa on viisi vertaisarvioitua artikkelia. Niistä kolme käsittelee kotimaista nykykirjallisuutta. Elli-Mari Aholan artikkeli tarttuu Seija Vilénin Kalevalaa intertekstuaalisesti hyödyntävään romaaniin Pohjan akka. Teoksen kertojien väliset suhteet ja hierarkiat aiheuttavat tulkinnallisia haasteita. Ahola argumentoi, että metalepsisten horjuttamaa kerrontaja maailmanrakennetta voidaan selkeyttää tutkimalla sisäistekijän roolia metalepsiksessä. Teosanalyysi toimii esimerkkinä sisäistekijän tarpeellisuudesta monitulkintaisen kokonaisrakenteen temaattisten merkitysten avaamisessa.

Kasimir Sandbackan artikkeli "Me halutaan käsikirjoittaa toinen maailma" on yksi pohdinta ja vastaus nykykirjallisuuden tarpeeseen kuvitella toisenlaisia todellisuuksia tilanteessa, jossa kytkös markkinatalouden ja liberaalin demokratian välillä on osoittautunut löyhäksi ja globaalin kapitalismin ekologiset rajat alkavat tulla yhä selvemmin vastaan. Artikkeli käsittelee metamodernia utooppisuutta kahdessa 2016 ilmestyneessä romaanissa, Emma Puikkosen Eurooppalaisissa unissa ja Riikka Pulkkisen Parhaassa mahdollisessa maailmassa. Sandbacka analysoi romaanien tasapainottelua postmodernin ironisen asenteen ja moderniin sisältyvän toiveikkuuden välillä. Myös kysymys utopiasta on olennainen: esiin nousee toisenlaisten maailmojen kirjoittamisen tärkeys ja välttämättömyys.

Riikka Rossin artikkelin aihe kumpuaa Naapuridialogien affektiiviset lähtökohdat-tutkimushankkeessa toteutetun lukupiirin aineistosta. Lukupiirissä luetun Marjo Niemen Kaikkien menetysten äiti -romaanin lukukokemusten luonnehdinnoissa toistuvat ahdistuksen tunteet ja jopa torjunta. Rossi tarkastelee romaanin ristiriitaisia tunnevaikutuksia - erityisesti empaattista ahdistusta - yhdistelemällä empiirisen tutkimuksen ja kirjallisuudentutkimuksen näkökulmia. Lukijan vaikeutta eläytyä tarinaan ja orientoitua empaattisesti henkilöhahmoihin kutsutaan kirjallisuudentutkimuksessa myös vaikeaksi empatiaksi. Artikkeli kehittää vaikean empatian tutkimusta kiinnittämällä huomiota poeettisiin piirteisiin: miten romaanin kerronnalliset ja tyylilliset keinot osallistuvat tunnevaikutusten tuottamiseen?

Saija Isomaan artikkeli "Poetiikka keskitason teoriana. Tieteenteoreettisia näkökulmia 1900-luvun poetiikkakeskusteluun" käsittelee modernissa kirjallisuudentutkimuksessa luotuja tapoja ymmärtää poetiikan tutkimuksen luonne. Isomaa tarkastelee kolmen keskeisen poetiikan koulukunnan, venäläisen formalismin, ranskalaisen strukturalismin ja Tel Avivin koulukunnan, teoreetikoiden näkemyksiä eritellen niitä suhteessa tieteenteoriassa tehtyyn erontekoon korkean tason ja keskitason teorian välillä. Artikkelissa sovelletaan Brian McHalea (1994) seuraten sosiologian piirissä (Robert K. Merton) syntynyttä ajatusta "keskitason teoriasta", jossa kohteen empiirinen tarkastelu voi vaikuttaa itse teorianmuodostukseen toisin kuin korkeimman abstraktiotason teorioissa.

Tero Tähtisen artikkeli "Pilvien kietomat vuoret. Wei Yingwun ja Wang Wein luontorunojen kuvitteelliset maisemat" vie konkreettisesta ja todenmukaisesta kuvastostaan tunnetun klassisen kiinalaisen luontorunouden 
pariin. Tähtisen mukaan kiinalaisessa perinteessä on pitkään ollut tilaa myös kuvitteellisille elementeille, mikä on kirjallisuushistoriassa kuitenkin jäänyt päätulkintalinjojen katveeseen. Tähtinen osoittaakin, että runoissa näkyvän todellisuuden pysyvyys ei ole yksiselitteinen asiantila, vaan runot voivat välittää myös maisemakokemusta horjuttavia ja kyseenalaistavia muotoiluja.

Laura Piipon lektio Jaakko Yli-Juonikkaan Neuromaanin kokeellista poetiikkaa käsittelevästä väitöstutkimuksestaan esittelee sitä, millaisiin yhteyksiin romaani asettuu kotimaisen kokeellisen ja kertomakirjallisuuden jatkumossa, aikansa kirjamediamaisemassa ja kirjallisuudentutkimuksessa. Piipon mukaan vuonna 2012 julkaistun Neuromaanin monimuotoisen poetiikan vaikutus on jo 2020-luvulle tultaessa nähtävissä: suomenkielinen proosa on hitaasti mutta varmasti löytänyt uusia raiteita.

Numerossa on neljä kirja-arvostelua: Laura Ekbergin arvio Arja Nurmen, Saija Isomaan ja Päivi Pahtan toimittamasta Kielten ja kirjallisuuksien mosaiikki: näkökulmina valta, periferia ja arki (2019); Päivi Kososen arvio Cecilia Petterssonin kirjasta Biblioterapi. Hälsofrämjande läsning i teori och praktik (2020); Päivi Heikkilä-Halttusen arvio Maria Laakson kirjoittamasta ja Johanna Rojolan kuvittamasta kirjasta Taltuta klassikko! (2019) sekä Joel Kuortin arvio Douglas Robinsonin käännösmukaelmasta Gulliver's Voyage to Phantomimia (2020), jonka alkutekstinä on Volter Kilven keskeneräiseksi jäänyt fantasiaromaani.

Avaimen päätoimittajina katsomme uteliaasti lehden tulevaisuuteen nykyhetken kirjallisuudentutkimuksen teemojen virittäminä. Suomessa tehtävä kirjallisuudentutkimus osallistuu kunnianhimoisesti eri tieteenalojen keskusteluihin ja tutkimuksen kehittämiseen. Siksi toivomme, että lehden sisällöt tavoittaisivat entistäkin laajemman yleisön.

Lotta Kähkönen \& Rïtta Jytilä

\section{Kirjallisuus}

Ameel, Lieven, Jussi Konttinen, Heidi Kuusisto, lida Salonen \& Saku-Petteri Urpo 2020. Toivoa tulevaisuudesta. Kaunokirjalliset tulevaisuusvisiot. Avain 17(3), 96-101. https://doi.org/10.30665/ av. 97363.

Haraway, Donna ]. 2016. Staying with the Trouble: Making Kin in the Chthulucene. Durham \& London: Duke University Press. 